\title{
Development and Validation of a Stability-Indicating HPLC Method for the Simultaneous Determination of trans-Resveratrol and cis-Resveratrol in an Injectable Solution
}

\author{
Esmeralda Mota-Lugo $\mathbb{i}$, Mariana Dolores-Hernández $(\mathbb{D}$, Elvia A. Morales-Hipólito $\mathbb{D}$, \\ Iris A. Blanco-Alcántara $\mathbb{D}^{\mathbb{D}}$, Hugo Cuatecontzi-Flores $\mathbb{D}$, and Raquel López-Arellano
}

\begin{abstract}
Laboratory of Pharmaceutical Development Tests, Multidisciplinary Research Unit, Faculty of Higher Education Cuautitlán, National Autonomous University of Mexico, Carr. Cuautitlán-Teoloyucan Km 2.5, San Sebastián Xhala, 54714 Cuautitlán Izcalli, Mexico
\end{abstract}

Correspondence should be addressed to Raquel López-Arellano; lopezar@unam.mx

Received 30 July 2021; Accepted 16 October 2021; Published 13 November 2021

Academic Editor: Cecilia Cagliero

Copyright (C) 2021 Esmeralda Mota-Lugo et al. This is an open access article distributed under the Creative Commons Attribution License, which permits unrestricted use, distribution, and reproduction in any medium, provided the original work is properly cited.

\begin{abstract}
trans-Resveratrol, a phytochemical compound with antioxidant power and various therapeutic effects, such as cardioprotective, chemopreventive, and neuroprotective, among others, has disadvantages of poor solubility and limited stability, creating difficulties for the development of new strategies for its quantification. This study developed and validated an analytical stability method for trans-resveratrol by high-pressure liquid chromatography with photodiode-array detection (HPLC-PDA), which allowed its quantification in the presence of its degradation products. The quantification of trans-resveratrol occurred at a retention time of $2.6 \mathrm{~min}$, with ammonium formate $(10 \mathrm{mM}, \mathrm{pH}=4) /$ acetonitrile, $70 / 30 \mathrm{v} / \mathrm{v}$, as mobile phase. The validation met the ICH Q2 criteria of specificity, method linearity $(2.8-4.2 \mu \mathrm{g} / \mathrm{ml})$, precision and accuracy, robustness, quantification limit $(0.176 \mu \mathrm{g} / \mathrm{ml})$, and detection $(0.058 \mu \mathrm{g} / \mathrm{ml})$. As degradation products, cis-resveratrol was observed at 3.9 min, which could be resveratrone in $3.2 \mathrm{~min}$ and five unidentified products in $0.7,1.0,1.4,1.8$, and $5 \mathrm{~min}$. Some solutions subjected to temperature stress of 40 and $60^{\circ} \mathrm{C}$, UV light, and acidic and basic hydrolysis exhibited colour changes. An analytical method was obtained by HPLC-PDA, which allowed quantifying the stability of trans-resveratrol in a fast and specific manner in the presence of its degradation products.
\end{abstract}

\section{Introduction}

trans-resveratrol $\left(3,5,4^{\prime}\right.$-trihydroxystilbene; t-RSV) is a polyphenolic phytoalexin mainly found in the skin of grapes and in at least 72 species of plants, peanuts, berries, cocoa, and almonds (Figure 1(a)). It has also been found in food products such as wine, chocolate, grape juice, and peanut butter [1]. It is one of the most studied phytochemicals due to its antioxidant property $[2,3]$, which provides cardiovascular [4-6], chemopreventive [7-10], antiplatelet [11], neuroprotector [12, 13], and antiaging [14] effects. One of the main disadvantages of t-RSV is that it has low bioavailability $[15,16]$, which is a consequence of its low aqueous solubility, limited stability, and extensive liver metabolism [2, 17-19]. As a result, it represents a major obstacle for biomedical applications. The research community is currently working to solve these problems by developing new drug delivery systems that may stabilize and protect t-RSV in order to enhance its pharmacological effects [20, 21].

Some studies have indicated that t-RSV had limited stability under the influence of light, basic $\mathrm{pH}$ levels, and temperature, which could cause isomerization to cisresveratrol (c-RSV) or t-RSV degradation. The c-RSV (Figure 1(b)) is not found naturally; it can be obtained from trans-resveratrol by exposure to sunlight, or by ultraviolet (UV) radiation at wavelengths of $254 \mathrm{~nm}$ or $365 \mathrm{~nm}$ [22-26]. Another degradation product reported is resveratrone 


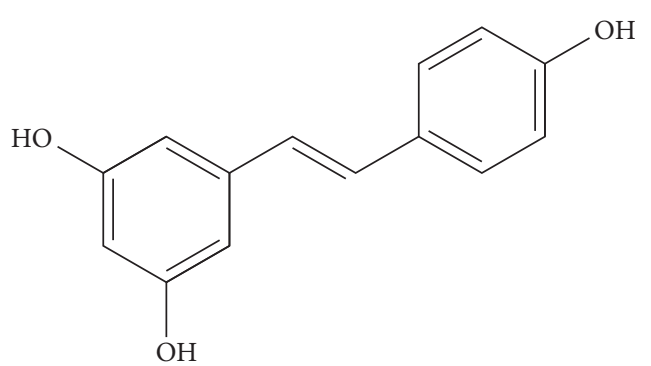

(a)

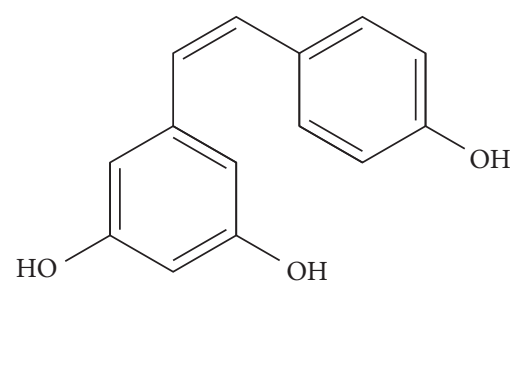

(b)

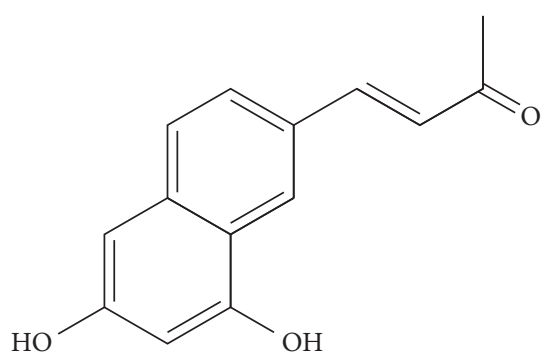

(c)

Figure 1: Chemical structure of compounds: trans-resveratrol (a), its isomer, cis-resveratrol (b), and its reported degradation product, resveratrone (c).

(Figure 1(c)), which is a degradation product of the isomer, c-RSV, that only occurs in ethanol solutions and acidic conditions, but not in water [24, 26, 27].

Most analytical methods reported for the identification and quantification of t-RSV have been applied in wine [28-30] or in pharmacokinetic studies [19, 31-33]. These methods are based on gas chromatography [29, 34], with tandem mass spectrometry detection and fluorometry $[35,36]$. However, some disadvantages of these methods are their high equipment costs and long retention times $[23,25,28,30,37,38]$. In contrast, studies that used highpressure liquid chromatography-UV-visible (HPLC-UV/ Vis) to deal with formulation development have only addressed analytical methods development, but not full validation. Until now, there are very few studies that addressed the quantification of t-RSV in the face of its degradation products generated by forced degradation $[25,39]$, and most of them have focused on photolytic studies with UV light [22-24, 26, 40].

Stability is the most important quality requirement for a pharmaceutical product. It allows a better choice of the components that will make part of the formulation and the appropriate packaging. Stability will also provide optimal storage conditions and expiration dates [41]. This way, the identity, effectiveness, potency, safety, and purity of pharmaceutical products will be assured until the moment of use. Quantification methods used in stability studies should be specific; i.e., they should be capable of quantifying only the substance of interest, without interference from some other component or degradation product of the sample. The International Conference on Harmonisation ( $\mathrm{ICH}$ ) provided recommendations in the guideline Q1A (R2) for conducting degradation and stress tests [42]. Liquid chromatography has been widely used to develop methods for determining stability. It has advantages over other methods with respect to the separation of all compounds in a single run. In addition, this method promotes easy identification of impurities and degradation products [43].

Considering the low stability and solubility of t-RSV, the hypothesis of the present study was that selection of the optimal conditions of the analytical method and its validation would allow the identification and specific quantification of trans-resveratrol in the face of different conditions of forced degradation. The goal was to develop an analytical method using high-pressure liquid chromatography (HPLC) coupled to a photodiode-array detector (PDA) that allowed the quantification of transresveratrol in a parenteral formulation in the presence of its isomer (c-RSV) and its degradation products. The method created was validated with respect to linearity, selectivity, precision and accuracy, robustness, and quantification and detection limit. trans-RSV was assessed under acidic, basic forced degradation, oxidative degradation, and photo degradation, as well as the effects of different temperatures.

\section{Materials and Methods}

2.1. Materials. The following chemicals and reagents were used in the present study: resveratrol (99\% purity), SigmaAldrich ${ }^{\circledR}$ (St. Louis, MO, USA); resveratrol, raw material (50\% purity) Alephquim ${ }^{\circledR}$ (CDMX, MX); PEG 400 and PG; ammonium formate (AF) $\left(99.0 \%\right.$ purity), Sigma-Aldrich ${ }^{\circledR}$ (St. Louis, MO, USA); RA-grade formic acid (89.2\% purity), Tecsiquim $^{\circledR}$ (CDMX, MX); HPLC-grade acetonitrile (ACN) (99.9\% purity); ACS-grade methanol (MetOH) (99.9\% purity); ACS-grade ethanol (EtOH) (99.9\% purity); ISO-grade hydrogen peroxide $\left(\mathrm{H}_{2} \mathrm{O}_{2}\right)$ (31\% purity), Fermont ${ }^{\circledR}$ (Mty, MX); sodium hydroxide $(\mathrm{NaOH})$ (98.4\% purity); RA-grade hydrochloric acid ( $\mathrm{HCl})(37.8 \%$ purity); and RA-grade glacial acetic acid (HAc) (99.9\% purity), JT Baker ${ }^{\circledR}$ (MA, USA). The water used in all the experiments was filtered using the Milli-Q water purification system (18.2 M $\Omega$ ), Millipore equipment.

2.2. Equipment. The samples were assessed using the following equipment: Waters ${ }^{\circledR}$ HPLC system; Waters ${ }^{\circledR} 616$ quaternary pump; multisolvent delivery controller system Waters ${ }^{\circledR}$ 6CE 600 controller; Waters ${ }^{\circledR} 717$ plus autosampler; and Waters ${ }^{\circledR} 996$ photodiode-array detector. Data collection and processing were performed using the Empower 2.0 software.

Robustness of the method was assessed using Waters ${ }^{\circledR}$ ACQUITY UPLC H-class system, equipped with Waters ${ }^{\circledR}$ quaternary multisolvent delivery controller system, Waters ${ }^{\circledR}$ FNT autosampler, CHA column heater, and Waters ${ }^{\circledR}$ PDA e $\lambda$ UPL diode array detector. Data collection and processing were performed using Empower 3.0 software, version 7.1, 2010. 
For the photo-stability test, the samples were placed in the UVLS-24 Model UV Lamp (UVP) chamber; under the effect of temperature at $40^{\circ} \mathrm{C}$, the samples were placed in a MAPSA oven, HDP-433 model and at $60^{\circ} \mathrm{C}$ in a Felisa oven, model 133.

2.3. Optimization Chromatographic Conditions. Halo ${ }^{\circledR} \mathrm{C} 18$ columns $(3.0 \times 75 \mathrm{~mm}, 2.7 \mu \mathrm{m}$, USA $)$ were used at a flow of $0.3 \mathrm{ml} / \mathrm{min}$ and an injection volume of $10 \mu \mathrm{l}$, containing $21 \mu \mathrm{g} / \mathrm{ml}$ of t-RSV raw material for the selection of the mobile phase. Different mixtures of $\mathrm{MetOH}, \mathrm{ACN}, \mathrm{HAc}(\mathrm{pH}=4$; $0.25 \%)$, and $\mathrm{AF}(10 \mathrm{mM})$ acidified with formic acid $(\mathrm{pH}=4)$ were used to choose the mobile phase. Once the mobile phase was chosen, the t-RSV response was compared with different columns: Agilent ${ }^{\circledR}$ Zorbax Rapid Resolution High Definition (RRHD) SB-C18 $(4.6 \times 50 \mathrm{~mm}, 1.8 \mu \mathrm{m}, \quad$ USA $) ;$ Agilent $^{\circledR}$ Zorbax Eclipse XDB C8 $\left(4.6 \times 50 \mathrm{~mm}, 1.8 \mu \mathrm{m}\right.$, USA); Waters ${ }^{\circledR}$ Symmetry C18 $\left(4.6 \times 75 \mathrm{~mm}, 3.5 \mu \mathrm{m}\right.$, Ireland); Inertsil ${ }^{\circledR}$ ODS$3 \mathrm{C} 18\left(33 \times 46 \mathrm{~mm}, 3 \mu \mathrm{m}\right.$, India); and Phenomenex ${ }^{\circledR}$ Luna C18 $(150 \times 4.6 \mathrm{~mm}, 5 \mu \mathrm{m}$, USA), conditioning the flow for each column with a pressure of 1200 psi.

2.4. Chromatographic Conditions. The Waters ${ }^{\circledR}$ Symmetry C18 column $(4.6 \times 75 \mathrm{~mm}, 3.5 \mu \mathrm{m}$, Ireland $)$ was used with $10 \mathrm{mM}$ ammonium formate mobile phase, acidified at $\mathrm{pH}=4$ with formic acid and acetonitrile, 70/30 v/v. The mobile phase had a flow of $0.9 \mathrm{ml} / \mathrm{min}$ and a run time of six minutes. The aliquot of the injected sample was $10 \mu \mathrm{l}$. The chromatograms were obtained at a wavelength of $307 \mathrm{~nm}$, since it is the maximum absorbance of t-RSV. The percentage of t-RSV concentration ( $\% \mathrm{t}-\mathrm{RSV}$ ) was calculated using (1), where $A_{\text {std }}$ corresponds to the peak area of the standard and $A_{\text {sample }}$ to the peak area of the sample:

$$
\% \mathrm{t}-\mathrm{RSV}=\frac{A_{\text {std }}}{A_{\text {sample }}} \times 100 .
$$

\subsection{Preparation of Standards and Sample Solution}

2.5.1. Standard Solution. The initial standard solution of t-RSV had a concentration of $21 \mu \mathrm{g} / \mathrm{ml}$, which was diluted with a mixture of $\mathrm{EtOH} /$ water, $1 / 1 \mathrm{v} / \mathrm{v}$, to prepare six standard solutions in a range of $0.525-16.8 \mu \mathrm{g} / \mathrm{ml}$ for the calibration curve.

2.5.2. Parenteral Solutions. Formulation 1 (F1) and Formulation 2 (F2) contained $3.5 \mathrm{mg} / \mathrm{mL}$ of $\mathrm{t}-\mathrm{RSV}$, both formulations developed in the laboratory. The placebo of F1 consisted of a mixture of EtOH/water/PEG 400, 10/30/60 v/ $\mathrm{v} / \mathrm{v}$, whereas the placebo of $\mathrm{F} 2$ consisted of a mixture of $\mathrm{EtOH} /$ water/PG, 15/25/60 v/v/v.

2.5.3. Sample Solutions Added. Five placebos were prepared with resveratrol, in a final concentration range of $2.8-4.2 \mu \mathrm{g} /$ $\mathrm{ml}$, corresponding to $80-120 \%$ of t-RSV. Each solution was prepared independently and randomly.
2.5.4. Sample for Forced Degradation. Standard t-RSV (STD), F1, F2, and their corresponding placebos were used for the forced degradation method. They were diluted to a final concentration of $4.2 \mu \mathrm{g} / \mathrm{ml}$ of t-RSV. For the effect of temperature, photolysis was diluted with EtOH/water, 1/1 v/ v. Acid hydrolysis was diluted with $0.1 \mathrm{~N} \mathrm{HCl}$, basic hydrolysis with $0.1 \mathrm{~N} \mathrm{NaOH}$, and oxidation with $3 \% \mathrm{H}_{2} \mathrm{O}_{2}$. Each solution was prepared independently and randomly.

2.6. Validation of the Method. The validation of the analytical method was performed in accordance with the recommendations established in the ICH Q2 guideline [44].

2.6.1. Specificity. Samples in triplicate of diluent solution were used as blank. Samples of solutions corresponding to $100 \%$ concentration of $\mathrm{t}-\mathrm{RSV}$, standard solution, placebo added of F1 and F2, placebo of both solutions, and samples of F1 and F2 were subjected to UV light stress $(\lambda=365 \mathrm{~nm})$, $0.1 \mathrm{~N} \mathrm{NaOH}, 0.1 \mathrm{~N} \mathrm{HCl}, 3 \% \mathrm{H}_{2} \mathrm{O}_{2}$, and a temperature of $60^{\circ} \mathrm{C}$ for 24 hours (h). In order to determine the specificity, it was first confirmed that there was no analytical response in the analyte retention time.

2.6.2. System Linearity. A 6-level calibration curve was performed in triplicate and independent of t-RSV standard solutions $(0.525-16.8 \mu \mathrm{g} / \mathrm{ml})$. Linearity was determined by linear regression analysis, calculating the correlation coefficient, determination coefficient, relative standard deviation, and confidence interval of the $y$-intercept.

2.6.3. Precision and Accuracy. The results and discussion may be presented separately, or in one combined section, and may optionally be divided into headed subsections.

2.6.4. Linearity of the Method. Linearity was assessed using a calibration curve in triplicate, with five concentration levels, in a range of $80-120 \%$ of placebos with t-RSV, which were prepared independently and by individual weighing. The recovery percentage and the relative standard deviation were determined, and a linear regression analysis was performed calculating the correlation coefficient, determination coefficient, the confidence intervals of the $y$-intercept, and the slope in order to determine the linearity of the method.

2.6.5. Quantification Limit and Detection Limit. The limit of detection (LOD) and limit of quantification (LOQ) were determined using the standard deviation of the $y$-intercept of the regression $\left(S_{\beta_{0}}\right)$ and the value of the slope $\left(\beta_{1}\right)$, withboth values of the calibration curve, using

$$
\begin{aligned}
& \mathrm{LOD}=3.3 \times\left(\frac{S_{\beta_{0}}}{\beta_{1}}\right), \\
& \mathrm{LOQ}=10 \times\left(\frac{S_{\beta_{0}}}{\beta_{1}}\right) .
\end{aligned}
$$


2.6.6. Robustness. The effect of intentional variations in the analytical conditions was assessed, namely: injection volume $(10 \pm 1 \mathrm{ml})$; mobile phase AF $10 \mathrm{mM} \mathrm{pH}=4$ and $\mathrm{ACN}$ (70/ $30 \pm 1 \%) ; \mathrm{pH}$ of the mobile phase of AF $10 \mathrm{mM}(\mathrm{pH}=4 \pm 1)$; and equipment change to UPLC. For the assessment, six loaded placebos corresponding to $100 \%$ of the analyte were analysed for each condition, calculating the absolute difference of the arithmetic mean corresponding to the area of the normal condition and to the modified condition.

2.7. Stress Degradation Studies. The forced degradation study was conducted with samples of STD, F1, F2, and placebos, which were diluted to a $4.2 \mu \mathrm{g} / \mathrm{ml}$ concentration. The forced degradation effect was obtained under acidic, basic, and oxidative conditions, at temperatures ranging from 40 to $60^{\circ} \mathrm{C}$, and the photolysis effect (UV light, $\lambda=365 \mathrm{~nm})$ and temperature effect $\left(4,25,40\right.$, and $\left.60^{\circ} \mathrm{C}\right)$ were assessed for $120 \mathrm{~h}$, in accordance with the recommendations established in the ICH Q1A and Q1B guidelines [42, 45]. The analyte was quantified from $0,24,72$, and $120 \mathrm{~h}$ of exposure to the degradation conditions.

2.7.1. Kinetic Study. For the kinetic analysis, the t-RSV concentration was measured at different time intervals $(0,24$, 72 , and $120 \mathrm{~h}$ ). The recovery percentages of t-RSV were used to determine the degradation kinetics for each sample, using first order equations and logarithm of the percentage of recovered t-RSV concentration (log\% RSV) as a function of time in h $(T)$, respectively [46], represented by (4), where $K_{0}$ represents the value of the unadjusted degradation constant, a value that was used to get the adjusted degradation constant $\left(K_{A}\right)$ obtained from the Arrhenius graph, given by $P$, which are percentiles taken at two or more temperatures of the study, following an Arrhenius model (5), where $T$ is the temperature in Kelvin degrees, $B=1 / 11605$ (Boltzmann's constant), and $A$ and $E$ are two unknown parameters [47].

$$
\begin{aligned}
& \log \% \mathrm{RSV}=-K_{0} \times T, \\
& K_{A}=P=A^{(-E /(B \times T))} .
\end{aligned}
$$

The procedure estimates the Arrhenius model and extrapolates a percentile for a normal operating temperature [47], in which the estimated percentile represents $K_{A}$. The time of $90 \%$ concentration (t90) was estimated using (6), where $C_{0}$ represents the initial concentration of t-RSV and $K_{A}$ represents the estimated degradation constant.

$$
\mathrm{t} 90=\frac{\log \left(C_{0} / 0.9\right) \times C_{0}}{K_{A}} .
$$

2.8. Data Analysis. All experiments were performed in at least triplicate, and data are expressed as mean \pm relative standard deviation (\% RSD). The results were statistically assessed by analysis of variance with $5 \%$ significance level $(p<0.05)$, using the statistical software STATGRAPHICS Centurion version XV.II (https://Statgraphics.Net, Madrid, Spain).

\section{Results and Discussion}

3.1. Optimization Chromatographic Conditions. Retention times $\left(t_{R}\right)$, capacity factor $\left(k^{\prime}\right)$, width $(w)$, and peak area $(A)$ were compared for the development of the method and its optimization. First, four mobile phases were tested with the Halo C18 column, namely: MetOH/HAc $(\mathrm{pH}=4 ; 0.25 \%)$, $60 / 40 \mathrm{v} / \mathrm{v} ; \mathrm{ACN} / \mathrm{HAc}(\mathrm{pH}=4 ; 0.25 \%), 30 / 70 \mathrm{v} / \mathrm{v} ; \mathrm{ACN} /$ Water/MetOH, 30/35/35 v/v/v; and CAN/FA acidified with formic acid, $\mathrm{pH}=4,10 \mathrm{mM}, 60 / 40 \mathrm{v} / \mathrm{v}$, choosing the last mentioned mobile phase, due to better chromatographic parameters $\left(t_{R}=1.6 \mathrm{~min}, w=81 \mathrm{~s}, A=873672, k^{\prime}=2.35\right)$ in comparison to those of the other mobile phases. Then, once the mobile phase was chosen, the column was selected assessing the Halo C18, Zorbax C18, Zorbax C8, Symmetry C18, ODS-3 C18, and Luna C18 columns. Two flow rates were used: one of $0.2 \mathrm{ml} / \mathrm{min}$ in the Zorbax C18, ODS-3, and Zorbax C8 columns and the other of $0.8 \mathrm{ml} / \mathrm{min}$ in the Luna C18, Halo C18, and Symmetry C18 columns, both columns with a pressure of 1200 psi (Figure S1 in supplementary information). The Symmetry C18 column was chosen for exhibiting the best chromatographic results in comparison to those of the other columns. It featured the shortest retention time $\left(t_{R}=2.6 \mathrm{~min}\right)$, a symmetric well-defined peak, a narrow peak ( $w=21 \mathrm{~s}, A=2715729)$, and a $k^{\prime}$ of 4.27 .

Subsequently, adjustments of the flow rate and the phase proportion were made using the Symmetry C18 column, mobile phase of ACN/FA $(\mathrm{pH}=4,10 \mathrm{mM}) 60 / 40 \mathrm{v} / \mathrm{v}$, and a sample of t-RSV subjected to UV light $(\lambda=254 \mathrm{~nm})$ for seven days to generate $\mathrm{c}-\mathrm{RSV}$. The purpose was to obtain the best resolution of the peaks and the shortest running time. The conditions with the best resolution were $70 \%$ of $10 \mathrm{mM}$ ammonium formate acidified with formic acid at $\mathrm{pH}=4$ and $30 \%$ acetonitrile at a flow of $0.9 \mathrm{ml} / \mathrm{min}$, with a resolution value of 2.91 and a $t_{R}$ of $2.6 \mathrm{~min}$ for t-RSV and $3.9 \mathrm{~min}$ for c-RSV (Figure 2).

3.2. Validation of the Method. The method optimized for the assessment of t-RSV stability was validated according to the established guidelines of the ICH Q2. The results obtained are shown in Table 1, and they met the acceptance criteria of the said guidelines.

The analysis of the samples subjected to stress for $24 \mathrm{~h}$ to assess the specificity of the method indicated the presence of degradation products. However, no additional signals were observed in the $t_{R}$ and analyte signal. This way, it was determined that there was no interference in the quantification and identification of t-RSV and that the signal was only due to the analyte (Figure 3). The linearity of the system obtained a correlation coefficient of 0.999 and a coefficient of determination of 0.998 , with \% RSD of 1.39 , criteria considered acceptable. The confidence interval of the $y$-intercept included zero. Subsequently, accuracy and precision obtained a recovery percentage of $100.16 \pm 1.47 \%$ and a percentage of residues less than 2 , as indicated in the guidelines. The linearity of the method obtained a recovery percentage of $100.11 \pm 1.20 \%$ and RSD of $1.19 \%$. The confidence interval of the $y$-intercept did not include zero, whereas the confidence 


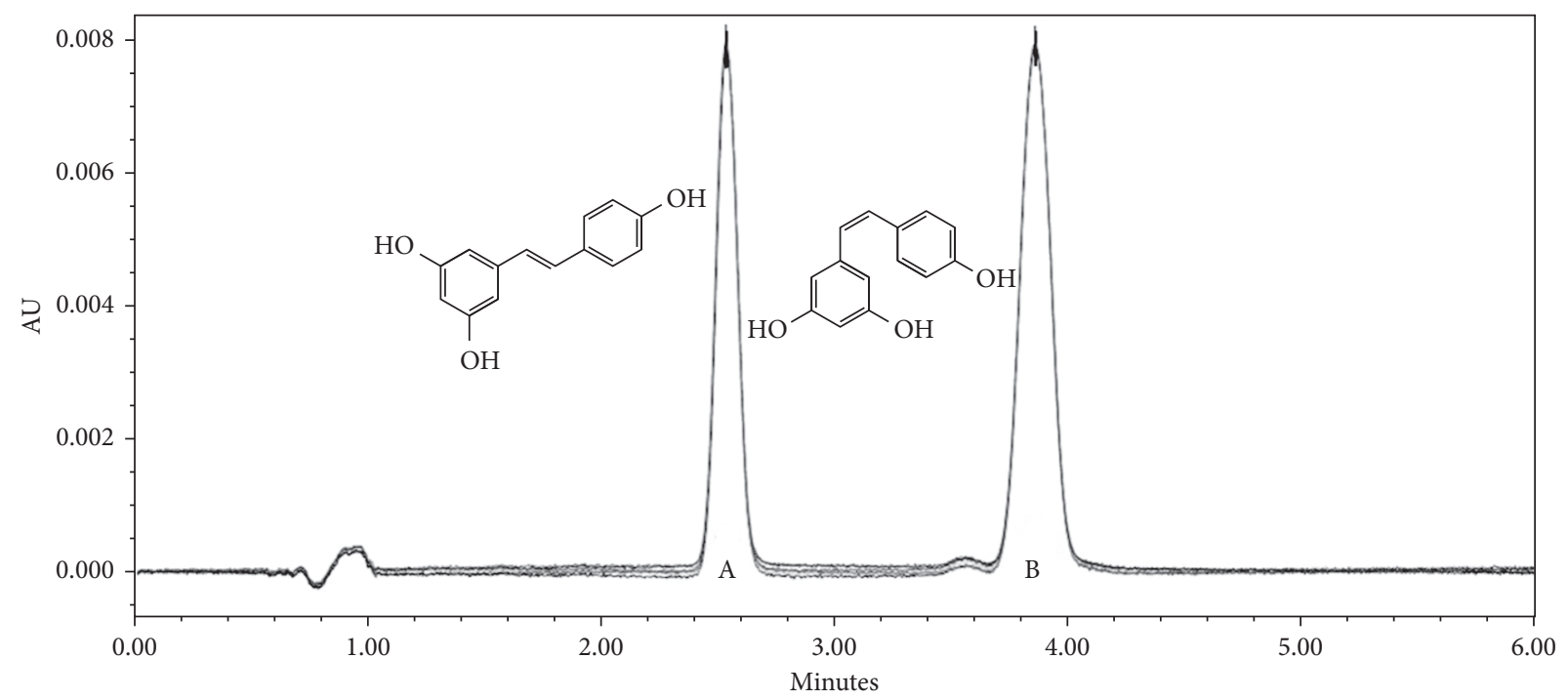

FIgURE 2: Chromatogram of trans-/cis-resveratrol. The following were obtained from the final working conditions: $10 \mathrm{mM}$ acetonitrile/ ammonium formate mobile phase $(\mathrm{pH}=4), 30 / 70 \mathrm{v} / \mathrm{v}$, at a flow of $0.9 \mathrm{ml} / \mathrm{min}$; t-RSV at a $t_{R}$ of $2.6 \mathrm{~min}$ (peak " $A$ "); and c-RSV at a $t_{R}$ of 3.9 min (peak "B"), with Symmetry C18 column.

TABLE 1: Summary of validation parameters of $\mathrm{t}-\mathrm{RSV}$.

\begin{tabular}{|c|c|c|c|c|c|c|c|}
\hline \multirow[b]{2}{*}{ Parameter } & \multicolumn{7}{|c|}{ Acceptance requirements } \\
\hline & $r(>0.998)$ & $r^{2}(>0.995)$ & $\begin{array}{c}\text { \% recovery } \\
(98-102 \%)\end{array}$ & $\begin{array}{l}\% \text { RSD } \\
(<2.0)\end{array}$ & IC $\left(\beta_{0}\right)$ includes 0 & $\begin{array}{c}\text { IC }\left(\beta_{1}\right) \\
\text { includes } 1\end{array}$ & $\left|d_{i}\right|(<2)$ \\
\hline Linearity of the system ${ }^{\mathrm{B}}$ & 0.999 & 0.998 & $*$ & 1.39 & -4729.09 at 1448.42 & $*$ & $*$ \\
\hline Accuracy and precision ${ }^{\mathrm{C}}$ & $*$ & $*$ & $100.16 \pm 1.47$ & 1.47 & -0.001 at 0.25 & 0.93 at 1.00 & $*$ \\
\hline Linearity of the method ${ }^{C}$ & 0.999 & 0.998 & $100.11 \pm 1.20$ & 1.19 & -0.06 at 0.23 & 0.94 at 1.02 & * \\
\hline Robustness & & & & & & & \\
\hline \multirow{2}{*}{ Mobile phase composition (FA/ACN) } & \multirow{2}{*}{\multicolumn{2}{|c|}{$\begin{array}{l}69 / 31 \mathrm{v} / \mathrm{v} \\
71 / 29 \mathrm{v} / \mathrm{v}\end{array}$}} & $100.36 \pm 0.51$ & 0.51 & $*$ & $*$ & 0.32 \\
\hline & & & $99.89 \pm 0.38$ & 0.39 & $*$ & $*$ & 0.16 \\
\hline \multirow{2}{*}{$\mathrm{pH}$ of $\mathrm{FA}$} & \multicolumn{2}{|c|}{$\mathrm{pH}=3$} & $100.00 \pm 0.81$ & 0.81 & * & * & 0.00 \\
\hline & \multicolumn{2}{|c|}{$\mathrm{pH}=5$} & $100.00 \pm 0.35$ & 0.35 & * & * & 0.00 \\
\hline Changing equipment & \multicolumn{2}{|c|}{ UPLC } & $100.01 \pm 0.24$ & 0.24 & $*$ & $*$ & 0.01 \\
\hline
\end{tabular}

$r=$ correlation coefficient; $r^{2}=$ determination coefficient; IC $\left(\beta_{0}\right)=y$-intercept confidence interval; $\% \mathrm{RSD}=$ relative standard deviation; IC $\left(\beta_{1}\right)=$ slope confidence interval; $\left|d_{i}\right|=$ absolute difference. ${ }^{\mathrm{A}}$ Mean $\%$ recovery \pm standard deviation; ${ }^{\mathrm{B}}=$ standards; ${ }^{\mathrm{C}}=$ fortified samples. ${ }^{*}$ Acceptance requirements are not required for the validation parameter.

interval of the slope included unity. Regarding LOD and LOQ, the values obtained were 0.058 and $0.176 \mu \mathrm{g} / \mathrm{ml}$ of $\mathrm{t}-\mathrm{RSV}$, respectively. The robustness was demonstrated by changes in the proportion of the mobile phase, change in $\mathrm{pH}$ of the mobile phase of AF $10 \mathrm{mM}$, and change of equipment, in comparison to normal conditions, expressed with its recovery percentage and its absolute value of arithmetic difference.

3.3. Stress Degradation Studies. The chromatograms of the method indicative of stability confirm the efficiency of the methodology developed and validated by HPLC coupled to DAD used to assess the stability of resveratrol in parenteral formulation (Figures S2-S6 in supplementary information). It can be observed that the detection was specific of t-RSV during the stability study performed, in which the peak of the analyte decreased due to forced degradation, but did not exhibit signal interference by any type of degradation product in the $t_{R}$ of the analyte, in any of the assessed conditions. Therefore, the created method was specific and suitable for the intended use. Furthermore, the placebos subjected to stability did not indicate the presence of degradation products or signals interfering with the t-RSV response.

Figure 4 illustrates the absorption spectra obtained from the chromatographic peaks of the t-RSV degradation products. It is worth mentioning that t-RSV had its $t_{R}=2.6 \mathrm{~min}$, and the maximum absorption was $307 \mathrm{~nm}$ (Figure 4(a)). The first peak, a degradation product of t-RSV, was at $t_{R}=0.7 \mathrm{~min}$, exhibiting maximum absorbance at 212 , 269 , and $328 \mathrm{~nm}$ (Figure 4(d)). It was found in the chromatograms from the $24 \mathrm{~h}$ under basic hydrolysis conditions in $\mathrm{F} 1$ and $\mathrm{F} 2$, under $\mathrm{UV}$ light in $\mathrm{F} 1$, on $72 \mathrm{~h}$ at temperatures of 40 and $60^{\circ} \mathrm{C}$ in $\mathrm{F} 1$, and in the STD sample at 4 and $25^{\circ} \mathrm{C}$ on $120 \mathrm{~h}$ under UV light. At minute 1.0, there was another degradation peak, with maximum absorbance at $214 \mathrm{~nm}$ (Figure $4(\mathrm{e})$ ). It was observed from the $24 \mathrm{~h}$ in the 

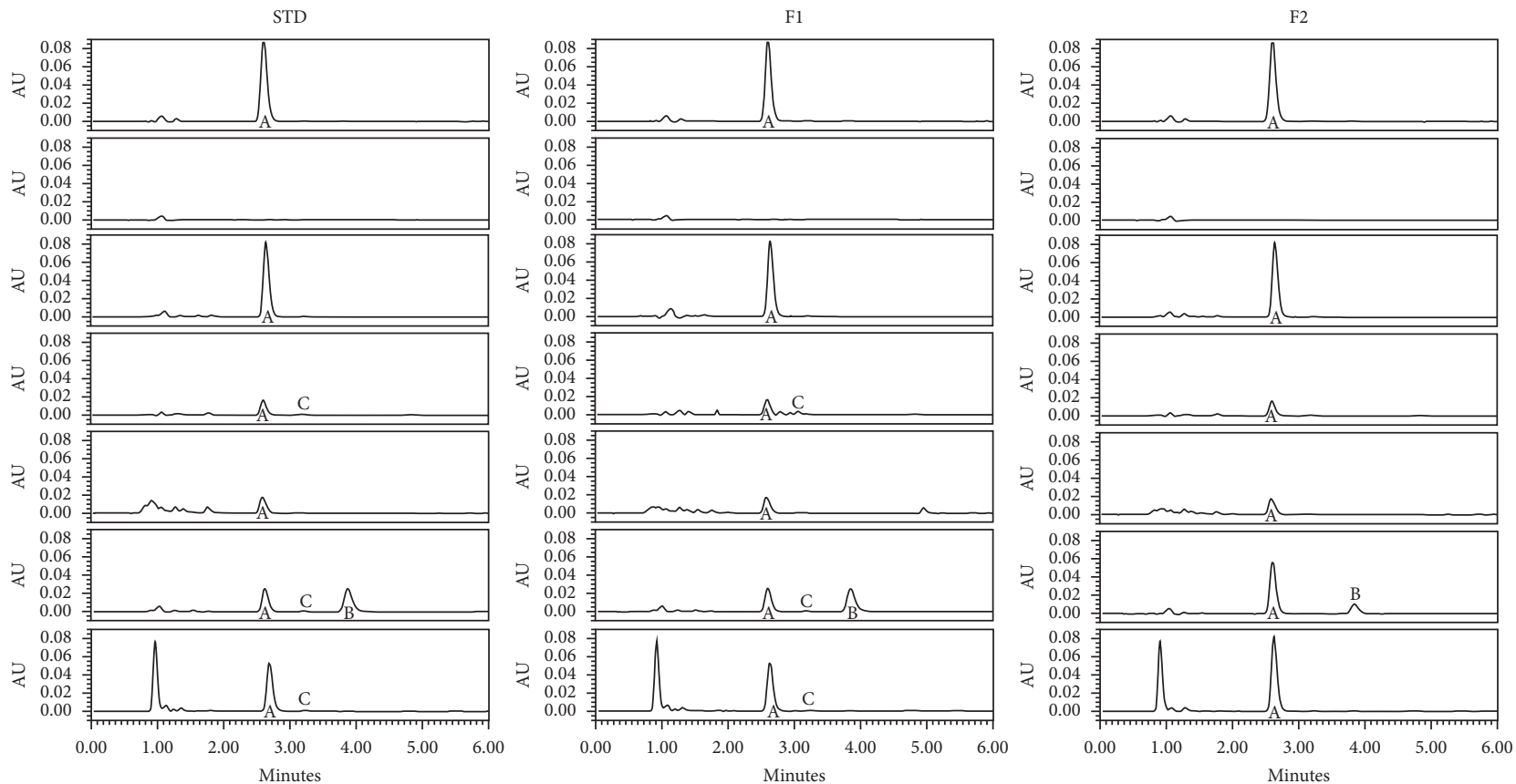

FIGURE 3: Specificity test of the method. Chromatograms of samples of t-RSV STD, F1, and F2 are observed without stress (I), their placebos (II), and under conditions of forced degradation for $24 \mathrm{~h}$ at a temperature of $60^{\circ} \mathrm{C}$ (III), acid hydrolysis (IV), basic hydrolysis (V), UV light (VI), and oxidation (VII). The peak " $\mathrm{A}$ " is trans-resveratrol, peak " $\mathrm{B}$ " is its isomer, and cis-resveratrol and peak $\mathrm{C}$ are believed to be resveratrone.

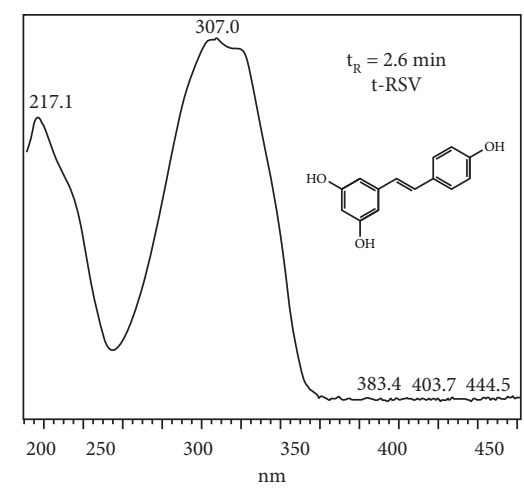

(a)

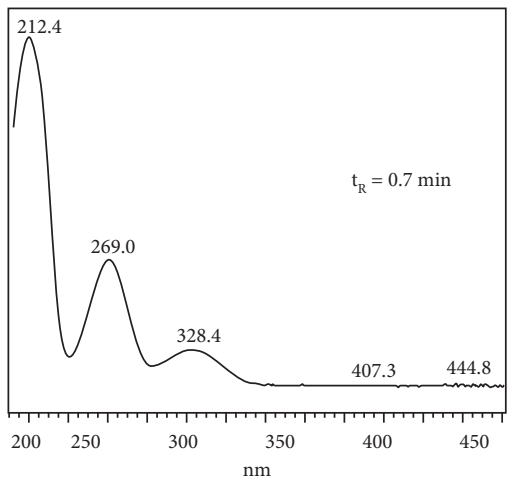

(d)

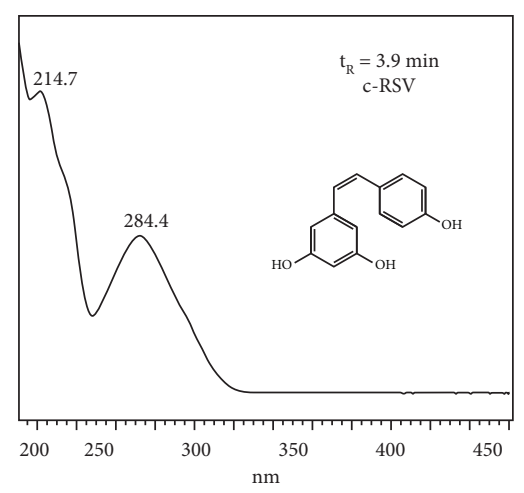

(b)

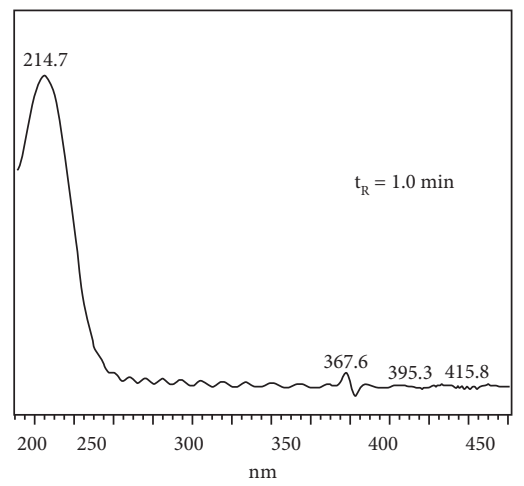

(e)

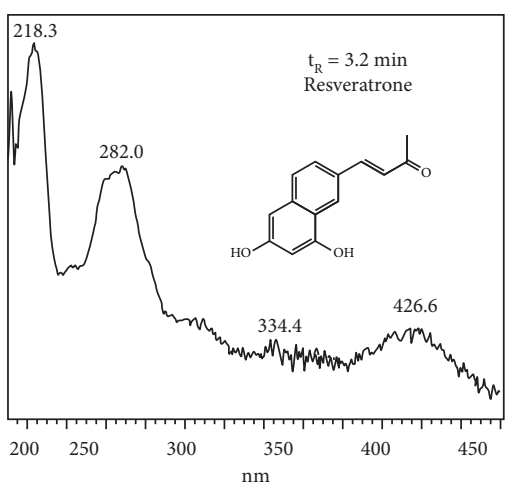

(c)

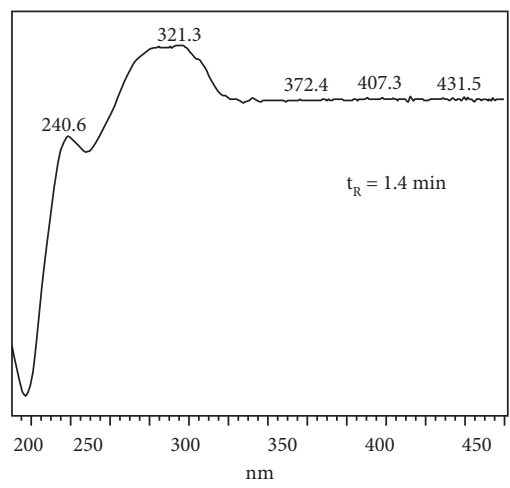

(f)

Figure 4: Continued. 


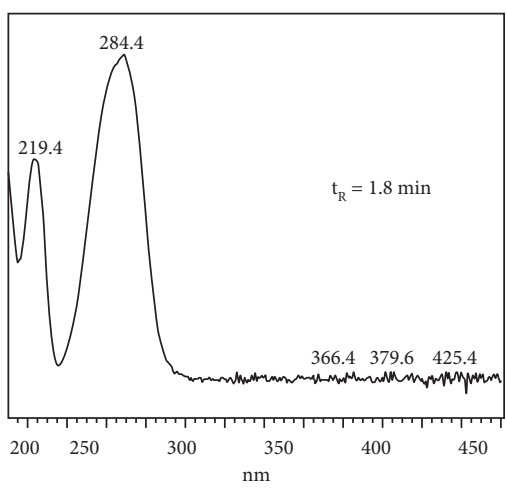

(g)

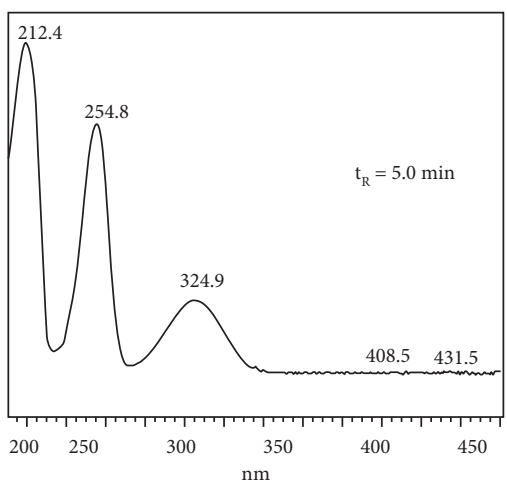

(h)

FIGURE 4: Spectra of degradation products of t-RSV. The spectrum of t-RSV (a) at a retention time $\left(t_{R}\right)$ of $2.6 \mathrm{~min}$, its isomer at 3.9 min, c-RSV (b), and its degradation product at $3.2 \mathrm{~min}$, which is believed to be resveratrone (c).

chromatograms of the effect of the temperature in $\mathrm{F} 1$ at $40^{\circ} \mathrm{C}$, in all acid and basic hydrolysis samples, and in UV light in F1 and F2, whereas in the STD, it was observed until the $120 \mathrm{~h}$ of analysis. The peak at $t_{R}=1.4 \mathrm{~min}$ exhibited maximum absorbance at 240 and $321 \mathrm{~nm}$ (Figure 4(f)), and it was observed in the chromatograms from $24 \mathrm{~h}$ in all samples of basic conditions, acid hydrolysis at $40^{\circ} \mathrm{C}$, and UV light of F1, from $72 \mathrm{~h}$ under acidic hydrolysis conditions at $40^{\circ} \mathrm{C}$ in $\mathrm{F} 2$, on $120 \mathrm{~h}$ in the t-RSV standard sample subjected to UV light, and at $60^{\circ} \mathrm{C}$ in $\mathrm{F} 1$ and $\mathrm{F} 2$. At $t_{R}=1.8 \mathrm{~min}$, another peak was observed with maximum absorbance of 219 and $284 \mathrm{~nm}$ (Figure $4(\mathrm{~g})$ ). It was observed in the chromatograms of the effect of temperature at $60^{\circ} \mathrm{C}$ on $72 \mathrm{~h}$ in $\mathrm{F} 2$ and on $120 \mathrm{~h}$ in $\mathrm{F} 1$, in acid hydrolysis at $40^{\circ} \mathrm{C}$ in $\mathrm{F} 1$ from $24 \mathrm{~h}$ and in $\mathrm{F} 2$ on $72 \mathrm{~h}$, whereas, in basic hydrolysis, it was observed in all samples from $24 \mathrm{~h}$. At the $t_{R}$ of $3.2 \mathrm{~min}$, the degradation peak exhibited maximum absorbance of 218, 282, and $426 \mathrm{~nm}$ (Figure 4(c)), which was believed to be the degradation product of t-RSV, identified as resveratrone [26]. However, further analyses should be performed with mass spectrometry or magnetic resonance imaging to elucidate the molecule. This peak was observed in the chromatograms of the effect of temperature at $60^{\circ} \mathrm{C}$ in $\mathrm{F} 1$ and $\mathrm{F} 2$ on $120 \mathrm{~h}$, in acid hydrolysis at $40^{\circ} \mathrm{C}$ in F2, and under UV light from $24 \mathrm{~h}$; however, it was not very significant in these chromatograms. The peak corresponding to c-RSV was observed at a $t_{R}$ of 3.9 minutes, with a maximum absorbance of $284 \mathrm{~nm}$ (Figure 4(b)), from $24 \mathrm{~h}$ in all samples exposed to UV light. The last peak was observed at a $t_{R}$ of 5.0 min (Figure 4(h)), with maximum absorbance of 212, 264, and $324 \mathrm{~nm}$, observed in the standard sample on $24 \mathrm{~h}$ in ambient light, and on $120 \mathrm{~h}$ in the formulation 1 in dark environment.

Table 2 illustrates the values obtained from the recovery percentages of t-RSV after $120 \mathrm{~h}$, the adjusted degradation rate constants $\left(K_{A}\right)$, and the life time at $90 \%$ of t-RSV (t90), which were obtained from the first order graph of the percentage logarithm of recovered concentration of t- RSV $(\log \% \mathrm{t}-\mathrm{RSV})$ with respect to time, and the Arrhenius graph at each degradation condition, respectively.

On the other hand, it is worth mentioning that colour change was observed in some solutions subjected to stress
(Figure 5). There was a colour trend; when the active principle (i.e., t-RSV) began to degrade, the colourless solution turned into yellow-orange, which darkened as the days went by, until it reached a brown-gray colour. In the literature, there are no data on colour changes in t-RSV solutions caused by degradation; however, it can be attributed to the nature and composition from which the raw material of the active principle comes, the excipients, and the interaction caused by their degradation products in the solution.

Regarding the results under acid hydrolysis conditions, F2 had greater degradation at a temperature of $40^{\circ} \mathrm{C}$, reaching $36.58 \%$ recovery on $24 \mathrm{~h}$, in comparison to the results obtained at $60^{\circ} \mathrm{C}$, with $52.53 \%$ recovery after $120 \mathrm{~h}$. On the other hand, F1 exhibited greater stability in comparison to $\mathrm{F} 2$, a fact that may have occurred due to the excipients, with a recovery percentage close to $12 \%$ at both temperatures on the $120 \mathrm{~h}$. However, the standard obtained lower degradation percentage than the formulations, recovering $88.06 \%$ at $40^{\circ} \mathrm{C}$ and $81.06 \%$ at $60^{\circ} \mathrm{C}$ on $120 \mathrm{~h}$. The standard obtained a $t 90$ of $174.91 \mathrm{~h}$ and $77.86 \mathrm{~h}$ at 40 and $60^{\circ} \mathrm{C}$, respectively. $\mathrm{F} 2 \mathrm{had}$ a $\mathrm{t} 90$ of $20.2 \mathrm{~h}$ at $60^{\circ} \mathrm{C}$, and $2.51 \mathrm{~h}$ at $40^{\circ} \mathrm{C}$. In the case of F1, a t90 of 7.02 and $5.85 \mathrm{~h}$ were estimated for 40 and $60^{\circ} \mathrm{C}$, respectively. The F2 solutions were those that exhibited colour change (Figure 5-IV), which turned yellow at both temperatures $\left(40\right.$ and $60^{\circ} \mathrm{C}$ ), during the $120 \mathrm{~h}$. On the other hand, in addition to yellow, the solutions at $40^{\circ} \mathrm{C}$ exhibited red/brown precipitate on 72 and $120 \mathrm{~h}$. This formulation rapidly degraded at a temperature of $40^{\circ} \mathrm{C}$, exhibiting $0 \%$ recovery of $\mathrm{t}-\mathrm{RSV}$ on $72 \mathrm{~h}$ - when the precipitate appeared-which could denote that the solid corresponded to a degradation product of the analyte.

With respect to basic hydrolysis, it was observed that, at $40^{\circ} \mathrm{C}, \mathrm{F} 2$ had better stability, with a recovery percentage of $41.39 \%$, whereas STD and F1 tended to degrade rapidly, with $4.41 \%$ recovery on $24 \mathrm{~h}$, and $19.44 \%$ on $72 \mathrm{~h}$, respectively. At a temperature of $60^{\circ} \mathrm{C}$, it was observed that the three samples featured the same stability pattern, obtaining on $24 \mathrm{~h}$ a recovery percentage of $5.49 \%$ of STD, $1.39 \%$ for $\mathrm{F} 1$, and $0.0 \%$ in F2. At the temperature of $40^{\circ} \mathrm{C}$, there were $t 90$ values of 2.46 , 2.89, and 1.54 hours for STD, F2, and F1, respectively, 


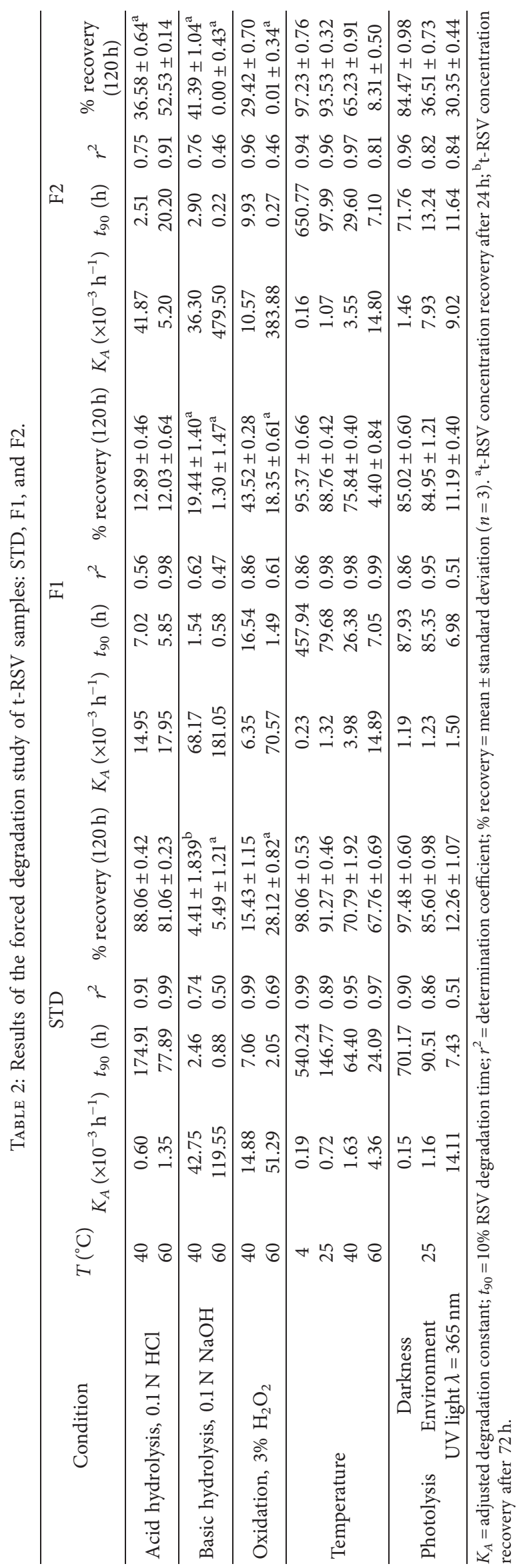




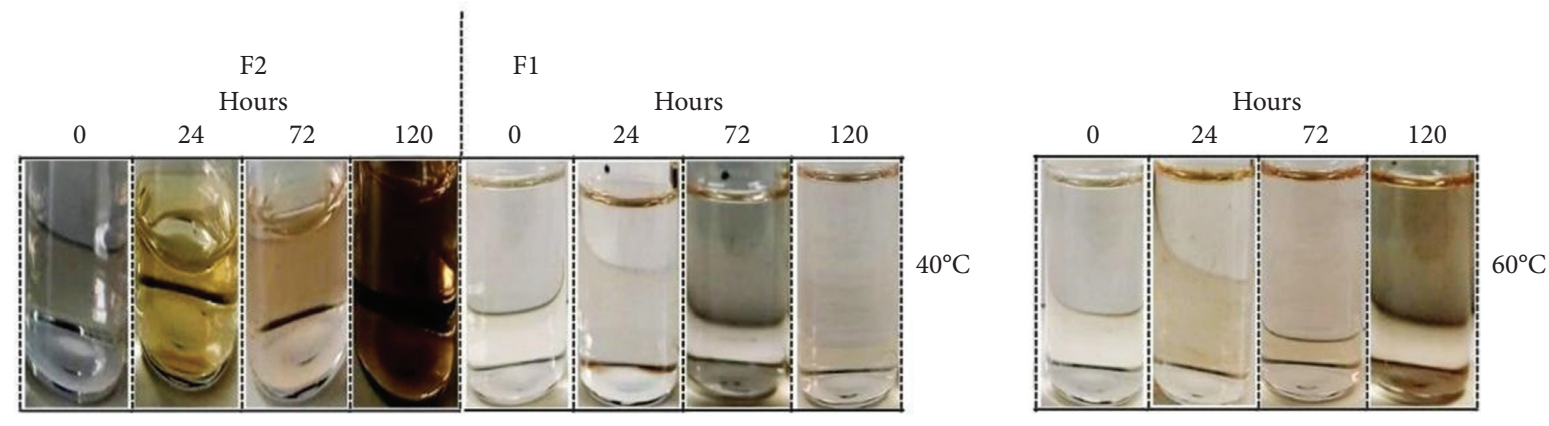

(a)

F2
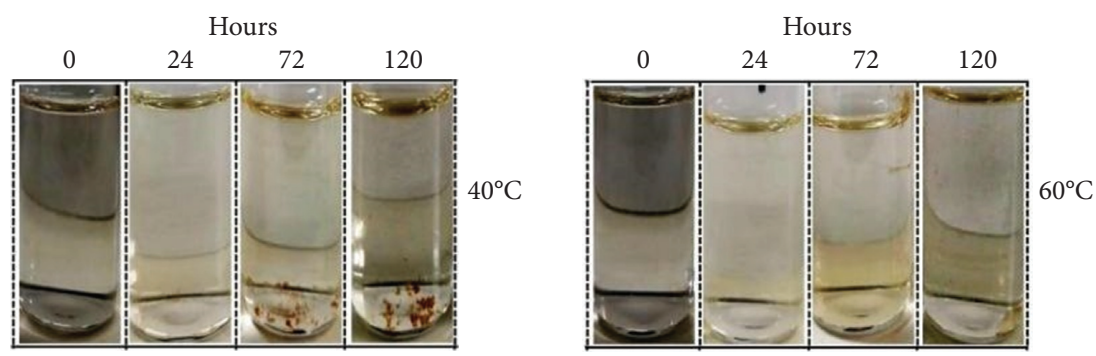

(b)

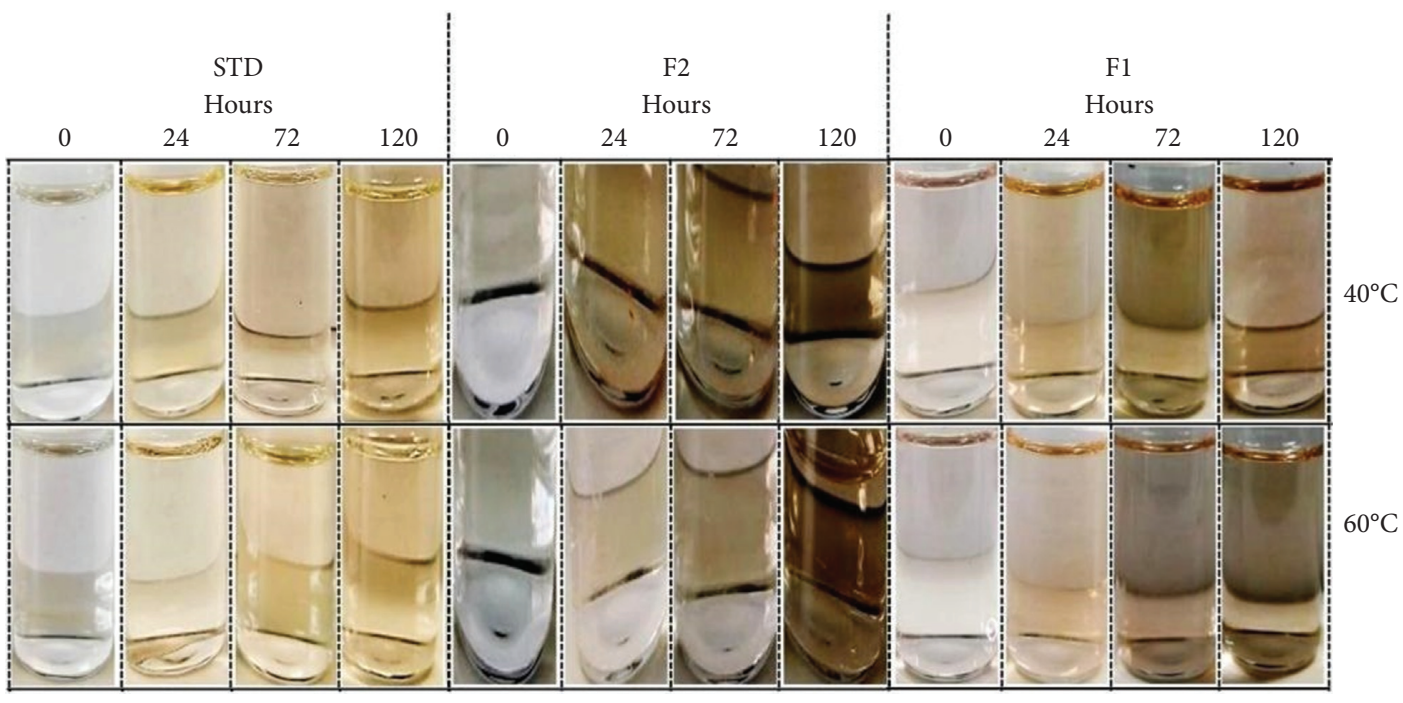

(c)

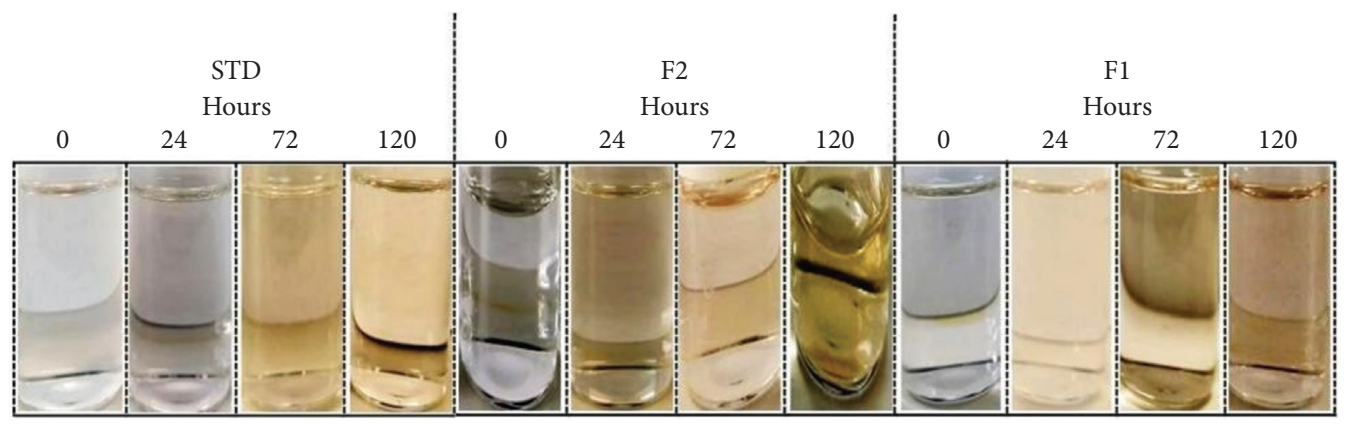

(d)

FIGURE 5: Colour change. Study on sample in t-RSV STD, F2, and F1 solutions subjected to forced degradation in temperature (III), acid hydrolysis (IV), basic hydrolysis (V), and exposure to photolysis with UV light at $\lambda=365 \mathrm{~nm}$ (VI). Note: the solutions that did not exhibit colour changes were not included in the image. 
whereas, for the temperature of $60^{\circ} \mathrm{C}$, the t90 values obtained were $0.88,0.22$, and $0.58 \mathrm{~h}$. According to the values obtained, it was considered that, in the three samples assessed, basic hydrolysis exhibited a higher rate (\%) of degradation in comparison to that of acid hydrolysis. It can be seen that t-RSV STD had better stability under acidic conditions, whereas, under basic conditions, F2 was more resistant to degradation. Figure $5-\mathrm{V}$ shows that the standard exhibited, both at 40 and $60^{\circ} \mathrm{C}$, a yellow coloration during the $120 \mathrm{~h}$ of assessment. $\mathrm{F} 1$, at 40 and $60^{\circ} \mathrm{C}$, exhibited a yellow coloration on $24 \mathrm{~h}$, whereas on 72 and $120 \mathrm{~h}$ it had a translucent browngray coloration. From its preparation, the solutions in formulation 16 turned translucent yellow (it was not possible to capture the colour in the photograph). On 72 and 120, at a temperature of $40^{\circ} \mathrm{C}$, the solutions were translucent yelloworange and, at $60^{\circ} \mathrm{C}$, they turned translucent brown.

Oxidation with $3 \% \mathrm{H}_{2} \mathrm{O}_{2}$ indicated that, at $40^{\circ} \mathrm{C}$, on $120 \mathrm{~h}$, F1 exhibited better stability, with a recovery percentage of $43.59 \%$, followed by F2 with $29.42 \%$, whereas the standard degraded faster, with $15.43 \%$ recovery. The recoveries obtained at a temperature of $60^{\circ} \mathrm{C}$ were $28.12 \%$ on $24 \mathrm{~h}$ for STD, $18.35 \%$ for $\mathrm{F} 1$, and $0.01 \%$ for $\mathrm{F} 2$. The $\mathrm{t} 90$ value for STD, at $40^{\circ} \mathrm{C}$, was $7.06 \mathrm{~h}$, and at $60^{\circ} \mathrm{C} 2.05 \mathrm{~h}$. For $\mathrm{F} 240^{\circ} \mathrm{C}$, it was $9.93 \mathrm{~h}$ and at $60^{\circ} \mathrm{C} 0.27 \mathrm{~h}$. In the case of $\mathrm{F} 1, \mathrm{t} 90$ were $16.54 \mathrm{~h}$ and $1.49 \mathrm{~h}$ for 40 and $60^{\circ} \mathrm{C}$, respectively. In this case, the formulations and the standard suffered a very rapid degradation; however, the $\mathrm{F} 1$ sample, at $40^{\circ} \mathrm{C}$, exhibited slower oxidation in comparison to F2 and STD, which had no colour changes.

With respect to temperature effect, it was observed that t-RSV exhibited better stability at $4^{\circ} \mathrm{C}$, temperature at which higher recovery percentages were obtained on $120 \mathrm{~h}$, which were greater than $95 \%$ in the three samples. At $25^{\circ} \mathrm{C}$ on $120 \mathrm{~h}$, the STD and F2 samples showed the same degradation trend, recovering more than $90 \%$, whereas for F1 the degradation rate was faster, with $88.76 \%$ recovery. At $40^{\circ} \mathrm{C}$, the degradation was greater for F2, recovering $65.23 \%$ on $120 \mathrm{~h}$, whereas F1 exhibited the lowest degradation value $(75.84 \%)$. At $60^{\circ} \mathrm{C}$ the degradation on $120 \mathrm{~h}$ for the standard was slower $(67.76 \%$ recovery) in comparison to the samples of F1 and F2, which achieved 4.40 and $8.31 \%$ recovery, respectively. At $4^{\circ} \mathrm{C}$, the STD sample exhibited the highest t90, with 540.24 h, whereas F1 had the lowest (457.94 h). Regarding ambient temperature $\left(25^{\circ} \mathrm{C}\right)$, the standard sample exhibited the highest value, with a t90 of $146.77 \mathrm{~h}$. The lowest value was observed in F1, with a 190 of $79.68 \mathrm{~h}$. At $40^{\circ} \mathrm{C}$, the $\mathrm{t} 90$ of the standard was 64.39 , whereas those of formulations 16 and 2 were 29.60 and $26.38 \mathrm{~h}$, respectively. At $60^{\circ} \mathrm{C}$, the $\mathrm{t} 90$ of $\mathrm{F} 2$ and $\mathrm{F} 1$ were similar, i.e., $7 \mathrm{~h}$, whereas the $t 90$ of the standard was $24.09 \mathrm{~h}$. In the case of thermal conditions of $60^{\circ} \mathrm{C}$ (Figure 5-III), it was observed in $\mathrm{F} 1$ that, on $24 \mathrm{~h}$, the solution exhibited a yellowish colour, on $72 \mathrm{~h}$, it turned orange, and, on $120 \mathrm{~h}$, it turned dark exhibiting a greyish-brown coloration. At $40^{\circ} \mathrm{C}$, from 24 to 120 h, F2 exhibited a translucent yellow coloration (it was not possible to capture the colour correctly in the photograph), at $60^{\circ} \mathrm{C}$, from 24 to $72 \mathrm{~h}$, it showed a translucent orange coloration and on $120 \mathrm{~h}$ translucent brown coloration.
In the photolysis test, on $120 \mathrm{~h}$, in the absence of light (i.e., darkness), the F2 and F1 samples had similar degradation behaviour $(84.47 \%$ and $85.02 \%)$, whereas the STD obtained recovery of $97.48 \%$. In ambient light, STD and F1 exhibited similar degradation values. Both formulations recovered about $85 \%$ on $120 \mathrm{~h}$, whereas for F2 the recovery was $36.51 \%$. In UV light, at a wavelength of $365 \mathrm{~nm}$, on $120 \mathrm{~h}, \mathrm{~F} 2$ was the one that obtained the lowest degradation percentage, with $30.35 \%$ recovery, whereas the STD and F1 samples showed very similar degradation kinetics, recovering 12.26 and $11.19 \%$, respectively. In darkness, t90 values of 701.17, 87.93, and $71.76 \mathrm{~h}$ were obtained for STD, F1, and F2, respectively. In ambient light, the t90 for STD was $90.51 \mathrm{~h}$, in F1 $85.35 \mathrm{~h}$, and in F2 13.24 h. In UV light, t90 of 7.43, 6.98, and $11.64 \mathrm{~h}$ were obtained for STD, F1, and F2, respectively. The solutions that exhibited colour changes were those exposed to UV light at $\lambda=365 \mathrm{~nm}$ (Figure 5-VI). On $24 \mathrm{~h}, \mathrm{~F} 1$ and F2 exhibited a light orange coloration, on $72 \mathrm{~h}$ it was yellow, and on $120 \mathrm{~h}$ the colour was light brown. The standard solutions exhibited a yellow coloration on 72 and $120 \mathrm{~h}$.

\section{Conclusions}

An analytical method indicative of stability HPLC was developed. It allowed quantifying t-RSV in parenteral formulation and raw material. It turned out to be fast, simple, and specific in the presence of its degradation products. In addition, it featured shorter times for retention, running, limit detection, and quantification in comparison to methods reported in the literature. The method assessed in the present study met the validation parameters established in the $\mathrm{ICH}$ Q2 validation guidelines. Its efficiency and selectivity were confirmed by the indicative stability method, which revealed that the stability of t-RSV samples was changed by basic hydrolysis, temperatures greater than $40^{\circ} \mathrm{C}$, and UV light $(\lambda=365 \mathrm{~nm})$. It was also possible to detect seven degradation products, from which their absorption spectrum was obtained. Colour change from translucent to yellow-orange was detected in the solutions subjected to forced degradation. The constant degradation for each t-RSV sample and its concentration time were determined by means of the first order equation. The samples were more stable at a temperature of $4^{\circ} \mathrm{C}$ and in the absence of light.

\section{Data Availability}

The data used to support the findings of this study are included within the article.

\section{Conflicts of Interest}

The authors declare that there are no conflicts of interest regarding the publication of this article.

\section{Acknowledgments}

The authors are grateful to CONACYT for the master's degree scholarship granted to Esmeralda Mota-Lugo (scholarship no. 761220). The present study was funded by the Project from DGAPA-UNAM (PAPIIT IT201620). 


\section{Supplementary Materials}

Figure S1. Chromatograms of t-RSV in the evaluated columns. Figure S2. Chromatograms of the effect of acid hydrolysis. Figure S3. Chromatograms of the effect of basic hydrolysis. Figure S4. Chromatograms of the oxidation effect. Figure S5. Chromatograms of the effect of light. Figure S6. Chromatograms of the effect of temperature. (Supplementary Materials)

\section{References}

[1] M. G. Novelle, D. Wahl, C. Diéguez, M. Bernier, and R. De Cabo, "Resveratrol supplementation: where are we now and where should we go?" Ageing Research Reviews, vol. 21, pp. 1-15, 2015.

[2] J. A. Baur and D. A. Sinclair, "Therapeutic potential of resveratrol: the in vivo evidence," Nature Reviews Drug Discovery, vol. 5, pp. 493-506, 2006.

[3] J. Martinez and J. J. Moreno, "Effect of resveratrol, a natural polyphenolic compound, on reactive oxygen species and prostaglandin production," Biochemical Pharmacology, vol. 59, pp. 865-870, 2000.

[4] N. Matsumura, S. Takahara, Z. H. Maayah et al., "Resveratrol improves cardiac function and exercise performance in MIinduced heart failure through the inhibition of cardiotoxic HETE metabolites," Journal of Molecular and Cellular Cardiology, vol. 125, pp. 162-173, 2018.

[5] K. S. Bhullar and C. C. Udenigwe, "Clinical evidence of resveratrol bioactivity in cardiovascular disease," Current Opinion in Food Science, vol. 8, pp. 68-73, 2016.

[6] M. Mokni, F. Limam, S. Elkahoui, M. Amri, and E. Aouani, "Strong cardioprotective effect of resveratrol, a red wine polyphenol, on isolated rat hearts after ischemia/reperfusion injury," Archives of Biochemistry and Biophysics, vol. 457, pp. 1-6, 2007.

[7] P. Signorelli and R. Ghidoni, "Resveratrol as an anticancer nutrient: molecular basis, open questions and promises," The Journal of Nutritional Biochemistry, vol. 16, pp. 449-466, 2005.

[8] C. K. Singh, M. A. Ndiaye, and N. Ahmad, "Resveratrol and cancer: challenges for clinical translation," Biochimica et Biophysica Acta, vol. 1852, pp. 1178-1185, 2015.

[9] M. Zielińska-Przyjemska, M. Kaczmarek, V. Krajka-Kuźniak, M. Łuczak, and W. Baer-Dubowska, "The effect of resveratrol, its naturally occurring derivatives and tannic acid on the induction of cell cycle arrest and apoptosis in rat C6 and human T98G glioma cell lines," Toxicology in Vitro, vol. 43, pp. 69-75, 2017.

[10] S. Moshawih, R. B. Rabiatul, S. Kalakotla, and Q. B. Jarrar, "Potential application of resveratrol in nanocarriers against cancer: overview and future trends," Journal of Drug Delivery Science and Technology, vol. 53, Article ID 101187, 2019.

[11] J. Y. Jang, J. H. Min, S. B. Wang et al., "Resveratrol inhibits collagen-induced platelet stimulation through suppressing NADPH oxidase and oxidative inactivation of $\mathrm{SH} 2$ domaincontaining protein tyrosine phosphatase-2," Free Radical Biology and Medicine, vol. 89, pp. 842-851, 2015.

[12] N. Singh, M. Agrawal, and S. Doré, "Neuroprotective properties and mechanisms of resveratrol in in vitro and in vivo experimental cerebral stroke models," ACS Chemical Neuroscience, vol. 4, pp. 1151-1162, 2013.

[13] M. C. Chiang, C. J. Nicol, and Y. C. Cheng, "Resveratrol activation of AMPK-dependent pathways is neuroprotective in human neural stem cells against amyloid-beta-induced inflammation and oxidative stress," Neurochemistry International, vol. 115, pp. 1-10, 2018.

[14] K. M. Kasiotis, H. Pratsinis, D. Kletsas, and S. A. Haroutounian, "Resveratrol and related stilbenes: their anti-aging and anti-angiogenic properties," Food and Chemical Toxicology, vol. 61, pp. 112-120, 2013.

[15] T. Walle, F. Hsieh, M. H. DeLegge, J. E. Oatis, and U. K. Walle, "High absorption but very low bioavailability of oral resveratrol in humans," Drug Metabolism and Disposition, vol. 32, no. 12, pp. 1377-1382, 2004.

[16] J. M. Smoliga and O. Blanchard, "Enhancing the delivery of resveratrol in humans: if low bioavailability is the problem, what is the solution?" Molecules, vol. 19, pp. 17154-17172, 2014.

[17] G. Kuhnle, J. P. E. Spencer, G. Chowrimootoo et al., "Resveratrol is absorbed in the small intestine as resveratrol glucuronide," Biochemical and Biophysical Research Communications, vol. 272, pp. 212-217, 2000.

[18] L. Biasutto, E. Marotta, S. Garbisa, M. Zoratti, and C. Paradisi, "Determination of quercetin and resveratrol in whole bloodimplications for bioavailability studies," Molecules, vol. 15, pp. 6570-6579, 2010.

[19] J. Rousova, K. Kusler, D. Liyanage et al., "Determination of trans-resveratrol and its metabolites in rat serum using liquid chromatography with high-resolution time of flight mass spectrometry," Journal of Chromatography B, vol. 1039, pp. 35-43, 2016.

[20] A. Amri, J. C. Chaumeil, S. Sfar, and C. Charrueau, "Administration of resveratrol: what formulation solutions to bioavailability limitations?" Journal of Controlled Release, vol. 158, pp. 182-193, 2012.

[21] A. C. Santos, I. Pereira, M. Pereira-Silva et al., "Nanotechnology-based formulations for resveratrol delivery: effects on resveratrol in vivo bioavailability and bioactivity," Colloids and Surfaces B: Biointerfaces, vol. 180, pp. 127-140, 2019.

[22] B. C. Trela and A. L. Waterhouse, "Resveratrol: isomeric molar absorptivities and stability," Journal of Agricultural and Food Chemistry, vol. 44, pp. 1253-1257, 1996.

[23] L. Camont, C.-H. Cottart, Y. Rhayem et al., "Simple spectrophotometric assessment of the trans-/cis-resveratrol ratio in aqueous solutions," Analytica Chimica Acta, vol. 634, pp. 121-128, 2009.

[24] T. Rodríguez-Cabo, I. Rodríguez, M. Ramil, and R. Cela, "Comprehensive evaluation of the photo-transformation routes of trans-resveratrol," Journal of Chromatography A, vol. 1410, pp. 129-139, 2015.

[25] Š. Zupančič, Z. Lavrič, and J. Kristl, "Stability and solubility of trans-resveratrol are strongly influenced by $\mathrm{pH}$ and temperature," European Journal of Pharmaceutics and Biopharmaceutics, vol. 93, pp. 196-204, 2015.

[26] M. Gaspar Tosato, P. Vicendo, A. H. Thomas, and C. Lorente, "Clearing up the photochemistry of resveratrol: effect of the solvent," Journal of Photochemistry and Photobiology A: Chemistry, vol. 367, pp. 327-331, 2018.

[27] I. Yang, E. Kim, J. Kang et al., "Photochemical generation of a new, highly fluorescent compound from non-fluorescent resveratrol," Chemical Communications, vol. 48, pp. 38393841, 2012.

[28] L. Minuti, R. M. Pellegrino, and I. Tesei, "Simple extraction method and gas chromatography-mass spectrometry in the selective ion monitoring mode for the determination of phenols in wine," Journal of Chromatography A, vol. 1114, pp. 263-268, 2006. 
[29] M. Fabjanowicz, J. Płotka-Wasylka, and J. Namieśnik, "Detection, identification and determination of resveratrol in wine. Problems and challenges," Trends in Analytical Chemistry, vol. 103, pp. 21-33, 2018.

[30] M. Careri, C. Corradini, L. Elviri, I. Nicoletti, and I. Zagnoni, "Direct HPLC analysis of quercetin and trans-resveratrol in red wine, grape, and winemaking byproducts," Journal of Agricultural and Food Chemistry, vol. 51, pp. 5226-5231, 2003.

[31] T. Nunes, L. Almeida, J.-F. Rocha et al., "Pharmacokinetics of trans-resveratrol following repeated administration in healthy elderly and young subjects," The Journal of Clinical Pharmacology, vol. 49, pp. 1477-1482, 2009.

[32] M. C. Menet, C. H. Cottart, M. Taghi et al., "Ultra high performance liquid chromatography-quadrupole-time of flight analysis for the identification and the determination of resveratrol and its metabolites in mouse plasma," Analytica Chimica Acta, vol. 761, pp. 128-136, 2013.

[33] Z. Qiu, J. Yu, Y. Dai, X. Chen, F. Huang, and N. Li, “A simple LC-MS/MS method for the simultaneous quantification of resveratrol and its major phase II metabolites: assessment of their urinary and biliary excretions in rats," Journal of Chromatography B, vol. 1048, pp. 85-93, 2017.

[34] D. M. Goldberg, J. Yan, E. Ng et al., "Direct injection gas chromatographic mass spectrometric assay for trans-resveratrol," Analytical Chemistry, vol. 66, no. 22, pp. 3959-3963, 1994.

[35] R. Preti, S. Vieri, and G. Vinci, "Biogenic amine profiles and antioxidant properties of Italian red wines from different price categories," Journal of Food Composition and Analysis, vol. 46, pp. 7-14, 2016.

[36] I. Durán-Merás, T. Galeano-Díaz, and D. Airado-Rodríguez, "Post-column on-line photochemical derivatization for the direct isocratic-LC-FLD analysis of resveratrol and piceid isomers in wine," Food Chemistry, vol. 109, pp. 825-833, 2008.

[37] J. B. Jiménez-Sánchez, E. Crespo-Corral, M. J. Santos-Delgado, J. M. Orea, and A. G.-U. Ureña, "Analysis of transresveratrol by laser ionization mass spectrometry and HPLC with fluorescence detection: comparison between both techniques," Journal of Chromatography A, vol. 1074, pp. 133-138, 2005.

[38] B. Kurangi, S. Jalalpure, and S. Jagwani, "A validated stabilityindicating HPLC method for simultaneous estimation of resveratrol and piperine in cubosome and human plasma," Journal of Chromatography B, vol. 1122, pp. 39-48, 2019.

[39] R. d. C. da Silva, J. A. Teixeira, W. D. Gonçalves Nunes et al., "Resveratrol: a thermoanalytical study," Food Chemistry, vol. 237, pp. 561-565, 2017.

[40] Y. Zhao, M. Shi, J. H. Ye, X. Q. Zheng, J. L. Lu, and Y. R. Liang, "Photo-induced chemical reaction of trans-resveratrol," Food Chemistry, vol. 171, pp. 137-143, 2015.

[41] M. Blessy, R. D. Patel, P. N. Prajapati, and Y. K. Agrawal, "Development of forced degradation and stability indicating studies of drugs - a review," Journal of Pharmaceutical Analysis, vol. 4, no. 3, pp. 159-165, 2014.

[42] ICH Harmonised Tripartite Guideline, "Stability testing of new drugs substances and products Q1a (R2)," vol. 4, 2003, https://database.ich.org/sites/default/files/Q1A\%28R2\%29\% 20Guideline.pdf.

[43] P. Sengupta, B. Chatterjee, and R. K. Tekade, "Current regulatory requirements and practical approaches for stability analysis of pharmaceutical products: a comprehensive review," International Journal of Pharmaceutics, vol. 543, pp. 328-344, 2018.

[44] ICH Harmonised Tripartite Guideline, "Validation of analytical procedures: text and methodology Q2 (R1)," vol. 4,
2005, https://database.ich.org/sites/default/files/Q2\%28R1\% 29\%20Guideline.pdf.

[45] ICH Harmonised Tripartite Guideline, "Stability testing: photostability testing of new drugs substances and products Q1B,”vol. 4, 1996, https://database.ich.org/sites/default/files/ Q1B\%20Guideline.pdf.

[46] C. Shein-Chung, Statistical Design and Analysis of Stability Studies, Chapman \& Hall, New York, NY, USA, 2007.

[47] Statgraphics Centurion XV.II., Arrhenius Graphics, StatPoint Technologies, Inc., Madrid, España, 2006. 